\title{
STUDENTS' PERCEPTION ON THE APPLICATION OF TIMED WRITING PRACTICE (TWP)
}

\author{
Muh Syafei \\ Universitas Muria Kudus, Indonesia
}

\begin{abstract}
This preliminary research is as a part of learning need analysis for developing a discourse based writing material with a timed-writing technique in an English teacher education department in Indonesia.In timed writing practice (TWP), students must write a paragraph on a sheet of paper without help in a given time limit.However, no empirical information on whether the students agree or disagree with the application of timed writing and the reasons behind their perceptions is not yet avaiable. The research subjects consist of 31 students who take writing course. The objectives are to investigate (1) the extent of the students' acceptance and (2) the reasons behind the acceptance on the application of timed-writing practice (TWP) in writing class. A qualitative analysis is administered by identifying and classifying contents of students' opinions and reflections expressed in the students' responses to questionare.Twenty five students $(81 \%)$ agree with the application of TW. Four students (13\%) disagree and 2 students $(6 \%)$ give no preference. Timed writing are perceived as (1) Encouraging Writing Activity, (2) Improving Time Management and Control, (3) Training Thinking Skills, (4) Improving Writing Skills, (5)Training Speed Writing, (6) Improving Soft Skills, (7) Giving Challenging Activity, and (8) Improving Concentration and Accuracy. The reasons from those who disagree are: (1) Feeling nervous and confused(2) Having insufficient preparation time, and (3) Expecting Variation of Activity. In conclusion,timed writing is mostly accepted and positively perceived by the students with very high category. Reasons from those who disagree must also be taken into consideration for future betterment. Based on the research findings, the timed writing, accordingly, can be used as a technique or a strategy to be integrated in a discourse-based writing materialfor students of English teacher education program.
\end{abstract}

Key words: Timed-Writing, Students' Acceptance, Reasons

\section{INTRODUCTION}

In this continuously changing field of ELT, how people learn and how learning materials are prepared and presented should be well accomodated. There are also some concerns in low students' writing skills and soft skills. The concerns must be addressed in balance. At present the writing materials are taken from general textbooks which do not properly match students' needs and do not apply a comprehensive discourse principles. The ideal course books are not yet available. Developing a course book belongs to "creating" which is the highest order of thinking in Bloom taxonomy. In this sense, I am motivated to develop something new in relation to learning materials for essay writing course in my own department and it can also be used for further sites which have similar condition and situation. I plan to develop an essay writing course book. 
This preliminary research is as a part of learning need analysis for developing a discourse based writing material with a timed-writing technique in an English teacher education department.In timed writing practice (TWP), students must write a paragraph on a sheet of paper without help in a given time limited.To develop a discourse-based course book with blended-learning and timed writing modes, the model proposed by Dick and Carey in Borg, Gall and Gall (2003) will be used. However, the system approach model has been adapted by the researcher to meet the condition of the research. The organization of the research procedure is as follows: Step 1 Learning need analysis, Step 2 Planning (Writing a syllabus), Step 3 Designing the materials (Writing the first draft), Step 4 Materials Evaluation, Step 5 Revising (Writing the final draft).

\section{Timed Writing Practice}

In TWP, the students must individually write a paragraph on a sheet of paper. They have only 30 minutes to complete the task without any access and help from their peers, teachers, textbooks, notes, dictionaries, cellphones and laptops. Initially some confussions and behavioral concerns took place but after several applications of TWP, students' original paragraphs improved in quality and length. After every TWP session, the students had to revise and improve their original compositions.

After TWP, they were strongly encouraged to have questions and reflections through group-work, peer's correction, and instructor's feedback. They were also allowed to access and make use of their smart gadgets and computers. All these efforts are to develop the best composition of the students. The TWP is administered weekly.

Writing Skills

Writing makes histories. Even in this digital era, writing is extremely important in today's society. Communications is transmitted more through writing than any other type of media. The most binding contracts and agreementsare written and signed. Writing is part of a creative project, whether it is a film, building, or a piece of literature. Without writing the flow of ideas halted shortly beyond the source. Writing achievement test scores are nowadays still used to diagnose strengths, weaknesses, and a basis for awardingprizes, scholarship, or degrees. They are also used in evaluating the influences of course of study, teachers, teaching methods, and other factors considered to be significant in educational practice. (Hosseini,et al, 2013).

\subsection{Discourse}

The writing skill is often perceived as the most difficult language skill since it requires a higher level of productive language control than other skills (Celce-Murcia \&Olshtain, 2000). On the other hand, register viewed as an instance of the context of situation, is configured by three inevitable factors; field, tenor and mode. Field refers to the subject matter about which the communication takes place; tenor points to the people of any social role and status participating in the communication; and mode refers to the channel via which messages are exchanged by the participants (Halliday, 1985). In addition, language, based on SFL, consists

of discoursesemantics and lexico-grammar levels. Discourse-semantics describes language from discoursal and semantic perspectives. From discoursal point of 
view, cohesion and coherence are of focal attention at the text level; and from semantic point of views three layers of meanings (ideational, interpersonal and textual) are investigated at the clause level. Cohesion refers to the logical and semantic relationships holding among various parts of a text by means of references, conjunctions and lexical relations. A course book should be in line with discourse principles.

\section{Soft Skills}

Timed writing empirically provides some positive points on the development of students' soft skills (Syafei, 2014). In his study, thestudents' soft skills and writing fluency were clearly observed. In doing the composition, the students also looked more relaxed and confident. The students hardly turned to their mates for help or discussions and accessed any notes even in the absence of their instructor. They had a better attendance, punctuality and time-management. Honesty, independence, descipline, determination, personality and independence were clearly obersved after PWP application. Copy-paste modus was totally eradicated in their paragraphs

In education setting, students' basic qualities (soft skills) such as attendance, punctuality, time-management, motivation, honesty, independence, descipline, determination, creativity and other relevant qualities should be integrated with the hard skills or writing skills in this discussion. Putra and Pratiwi (2005) call such basic qualities soft skills while citing Patrick S O'Brian (in Making College Count) who classify the skills into "COLLEGE" or seven Winning Characteristics: (1) Communication Skills (2) Organizational Skill (3) Leadership (4) Logic (5) Effort (6) group Skill and Ethics. The Directorate of Higher Education of Indonesia (2008:iii) mentions that soft skills are basically strategic, attitudinal, and behavioral skills. Mitsubishi Reserach Institute (2000) as cited by Elfindri (2010) find out that the success of university graduates depends on emotional and social maturity (40\%), networking (30\%), academic skills $(20 \%)$ dan finacial capacity (10\%). A survey by NACE (National Association of Colleges and Employers) on the qualities of university graduates (in Putra and Pratiwi, 2005, p 5) mention that successful employment requires $82 \%$ soft skills dan 18\% hard skills.Cicero as quoted by Santosa in Megawangi (2004) argues "Within the character of the citizen, lies the welfare of the nation".

\section{Blended Learning}

Timed writing practice (TWP) should be intergrated in updated teaching and learning processes. One of them is blended-learning. It is defined as a combination of face-to-face, computer, and self-study modes in a single teaching and learning environment. Sometimes called "hybrid learning," blended learning uses a mix of training strategies to deliver the best results. Any program that combines traditional classroom training with computer-based or online training is reaping the benefits of blended learning.

Whittaker's (2005-2008) case study reports on the redesign process of a range of blended learning English language courses in the Armed Forces of Bosnia and Herzegovina. In studies contrasting blends of online and face-to-face instruction with conventional face-to-face classes, blended instruction has been more effective." (US 
Dept of Education, 2010). http://www.knowledgewave.com/blog/benefits-of-blendedlearning.

Blended Learning has become one of the most common ways to teach EFL (English as a Foreign Language) due to its double component, which integrates Face-toFace classes with virtual learning in order to offer students a wide range of materials and resources organized in a methodological way. Over the years, teachers and students have changed the way this educational process is seen because new technologies have been implemented and teachers have to propose new ways of working to display materials that complement EFL Face-to-Face classes. However, the implementation of a Blended Course must have a pedagogical foundation for each setting where it is planned in order to be developed (Flórez, et al, 2013).

\section{Paragraph Writing}

Paragraph Writing Class at EED of UMK is the first formal writing class for the students of EED UMK of second semester. The aim of this course is to develop students' competence to compose well-organized paragraphs. A basic unit in writing that consists of a group of related sentences which make one idea or topic may represent a paragraph. The initial word of a paragraph is physically indented about one inch or five spaces or letters from the left margin of the page. A paragraph may consist of some sentences. Some topics are more difficult than others and take more words to develop. The number of sentences is not very important but the length of a paragraph should be enough to develop the main idea clearly (Fawcett and Sandberg, 1984). Every line of a paragraph is extended to the right-hand margin. The rest line of the line is left blank if the last word of the paragraph comes before the end of the line.A paragraph has three major parts: a topic sentence, some supporting sentences, and a concluding sentence. The topic sentence states the main idea of the paragraph and also limits the topic to one area or two areas. The specific area is known as the controlling idea (Oshima and Hogue, 1981). They further argue that a paragraph should also represent coherence and unity.

In this study, the students had to compose a paragraph on an assigned topic. TWP is administered weekly at the beginning of the Paragraph Writing. The students must individually write a paragraph on a sheet of paper. They had only 30 minutes to complete the task without any access and help from their peers, teachers, textbooks, notes, dictionaries, cellphones and laptops. The TWP in this paper was not intended to become an assessment instrument of the course. It is only one of activties in the course and it functions as one of the techcniques to improve students' writing skills. TWP was not aimed at giving a final score of the composition but it was employed as a technique to train students to write paragraphs well and better

\section{Timed Writing Practice (TWP)}

The idea of TWP is not new. This paper adopts Oshima and Hogue's (2006:17) ideas of Writing Under Pressure. This practice gives a training for students to think and write quickly. This is also similar to deal with an essay examniantion. It may choose to alter the time limit or assign other topics depending on the needs and interests of the class. The class have a topic to write a well-organized paragraph. It gives a time limit and students have to make use of 
the time. It is suggested that 1 to 2 minutes at the beginning for thinking of the ideas and organizing them, 1 to 2 minutes at the end for checking the work for errors and the remaining time for writing. The idea of TWP is also in line with the Test of Written English of TOEFL (of ETS: 1996). The testees are required to plan, write and do any necessary changes to improve the composition in thirty minutes. The pressure writing practice also resembles one of Writing Tasks of International English Language Testing System (IELTS) in which testees have to spend about 40 minutes to write a composition on an assigned topic (Loughheed, 2008).

The term timed writing, also known as free writing, speedwriting or fluency writing, is a way of assessing a student's language acquisition. The purpose of timed writing is to provide the creative pump: shortening writing time is to make sure that someone has more to say than time to say it. The frustration of stopping creates the impetus to write more. The writers become more interested in the ideas and thoughts to express and they are less self-conscious about the times it's taking to write. This exercise also helps develop confidence and establishes creative tension. (https://web.facebook.com/search/top/?q=timed\%20writing). The length of timing is really relative up to the need and the topic. Some teachers do not show the students the timer so that they focus on their writing and not the time. Another option is to start longer and decrease the time as students' abilities grow.

Some empirical evidences indicate that timed-writing is useful in developing students' writing skills. Some of them are as follows. Rogers (2018) examined the use of timed practice with repeated writings to promote sentencewriting fluency. Once students have learned to compose sentences accurately (i.e., with minimal grammar, spelling, capitalization, and punctuation errors), the next step in advancing as a writer is to write fluently. Writing fluency is defined as writing with accuracy and speed (Johnson \& Street, 2013 in Rogers, 2018). Students who do not write sentences fluently can find writing cognitively demanding because they spend much of their energy writing individual letters legibly and spelling words correctly (Gillespie \& Graham, 2014 in Rogres, 2018). The timed-writing practice can be a drain on students' working memories so that they often do not spend time revising what they have written. After fluency, there is less demand on their working memories and they can devote their cognitive efforts to more complex writing tasks and skills such as writing paragraphs, essays, and using specific writing strategies (Graham, Gillespie, \&McKeown, 2013 in Rogers, 2018). Timed practice activities have been shown to improve students' writing fluency. Timed practice can refer to any exercise in which students have a specified amount of time to write (Datchuk, 2017 in Rogers, 2018).

Ayotte (2018) was to investigate the effects of regular timed-writing sessions in the intermediate-level foreign language classroom. She argued that today's foreign language pedagogy tend to encourage success with regard to oral communicative skills, writing may be a skill that has fallen to the wayside.

Similarly, implementing timed-writing exercises can benefit foreign language students. According to Kresovich (1991) in Ayotte (2018), timed-writing encourages students to get ideas on paper. In addition, it aids learners in avoiding word-for-word translation from L1 to L2 because the very nature of timed writing 
does not allow ample time for students to translate. Timed-writing has several advantages: it is a good way to encourage novice writers to overcome the so called writer's block and it gives students the opportunity to write, which may lead to an improvement in the quality of their writing. This study provides evidence that regular implementation of timed-writing can be effective in fostering FL writing development. It also showed that requiring students to write regularly during class time gives them a greater sense of self-confidence with their L2 writing skills. Accordingly, the teachers should help students expand their writing by providing ample opportunities for writing during class, for group collaboration, for brain storming sessions, and for corrective feedback - all of which may be useful tools in developing better FL writers. The evidences should lead instructors to believe that timed-writing instruction and its implementation deserve an important place in the FL classroom.

Additionally, timedwriting promotes thinking in the L2, which can decrease the amount of translation errors that take place between the L1 and the L2, and the practice of timed-writing increases confidence as students become aware of their own writing capabilities with practice, collaboration, revision, and feedback (Jacobs, 1986; Kresovich, 1991; Lane \& Perrin, 1984; Walter, 1987 in Ayotte, 2018).

The above discussions have provided theoretical and empirical evidence of the timed writing roles in writing classes. However, no empirical information on whether the students agree or disagree with the application of timed writing and the reasons behind their perceptions is not yet avaiable. This paper quantitatively and qualitatively describes (1) To what extent is the students' acceptance on the application of timed-writing practice (TWP) in writing class, (2) To explore the reasons behind the students' acceptance on the application of timed-writing practice (TWP) in writing class.

\section{METHOD}

\section{Research Design}

Mixed method was used in the research. A quatitative procedure was used describe To what extent is the students' acceptance on the application of timedwriting practice (TWP) in writing class. Meanwhile a qualitative procedure was used to reveal the reasons behind the students' acceptance on the apllication of timed-writing practice (TWP) in writing class.

\section{Subjects}

Research involves human participants (often referred to as "subjects") may take place in many locations around the university campus or in locations off campus. Research with human participants is conducted by many schools and departments. The subjects of this research consist of with 31 students of writing class of odd semesterin academic year 2018/2019.

\section{Instrument}

An open ended questionnaire was used to reveal students' acceptance and reasons behind the their' acceptance on the apllication of timed-writing practice (TWP) in 
writing class. The questionaire consists of two open enden questions as follows: (1) Do you agree or disagree with the application of timed-writing in writing class? (2) Please explain your reasons of your posistion.Open-ended questions prompt people to answer with sentences, lists, and stories, giving deeper and new insights. The use open ended questions is also to secure the validity of tha data. The most important benefit of open-ended questions is that they allow the researchers to find more than you anticipate. Subjects also often reveal surprising data in responding the question.

\section{Data Collection}

As mentioned previously, the subjects have a couple of questions to answer and they have to present their responses in the form of written responses. When necessary, a direct clarification to the subjects is done. The questions investigate the students' open opinions and reflections on the extent of the students' acceptance and the reasons behind the acceptance on the application of timed-writing practice (TWP) in writing class. The data collection took place between November 21 and 22, 2019.

\section{Data Analysis}

A quantitative-qualitative analysis is administered by identifying and classifying contents of students' opinions and reflections expressed in the students' responses especially associated with the extent of the students' acceptance and the reasons behind the acceptance on the application of timed-writing practice (TWP) in writing class. The responses were quantiatively analyzed using frequencies and percentages. The highest percentages of the answers of each question were considered representing the students' acceptance on the application of TWP.

The percentage is calculating by dividing the frequency by the total of the respondents and then the results is multiplied by $100 \%$ and put into the four categories as follows.

Table 1. The Categories of Students' Acceptance of Timed Writing

\begin{tabular}{lcc}
\hline & Acceptance Percentage $(\%)$ & Category \\
\hline 1 & $0-20$ & Very low \\
2 & $21-40$ & Low \\
3 & $41-60$ & Fair \\
4 & $61-80$ & High \\
5 & $81-100$ & Very High \\
\hline
\end{tabular}

The reasons behind the acceptance on the application of timed-writing practice (TWP) are qualitatively indetified from the students' responses and classified according the categories of the students reasons.

\section{FINDINGS AND DISCUSSION}

After analyzing the content of the responses from 31 students who took part in writing classes, this exploration presents the descriptive and qualitative findings as follows.

\section{The Students' Acceptance on the Application of Timed Writing Practice}

Quatitative data of this reaserach indicates to what extent is the students' agreement on the application of timed writing practice. The subjects who are 
purposively selected of this study consists of 31 students of a English Teacher Education Department of Universitas Muria Kudus. Twenty five students (81\%) agree with the application of TWP in writing Class. Four students (13\%) disagree with the application of TWP, meanwhile 2 students $(6 \%)$ give no opinion of agreement. This can be represented by the following table.

Table 2. Student's Acceptance on the Application ofTimed Writing Practice

\begin{tabular}{cccc}
\hline Application of TWP & Number of Subjects & Percentage \% & Category \\
\hline Agree & 24 & 81 & VeryHigh \\
Disagree & 6 & 13 & Very Low \\
No Opinion & 2 & 6 & Very Low \\
Total & 31 & 100 & \\
\hline
\end{tabular}

The students' agreement on the application of timed writing practice belongs to very high category. The quantitative finding shows most students agree with the application of timed writing practice. The appication of TWP can be used for the future classes of writing without neglecting opinons fro those who disagree although it belongs to very low category.

\section{The Students' Reasons on Acceptance of Timed Writing Practice (TWP)}

This section describes the expressions and reflections of the subjects to a question whether they agree with the application of timed writing in their writing classes. The followings are some examples of students' expression and reflections in relation to the application of timed writing. Those who accept or agree with the application of timed writing (81\%) gives the following reasonings:

\section{Agreement on Application of Timed Writing Practice}

After analysing responses which contains data of reasons for accepting the application of timed writing, the researcher classify the reasons into the followings(1) Encouraging Writing Activity, (2) Improving Time Management and Control, (3) Training Thinking Skills, (4) Improving Writing Skills, (5)Training Speed Writing, (6) Improving Soft Skills, (7) Giving Challenging Activity, and (8) Improving Concentration and Accuracy. They are the positive points of timed writing practice in writing class. The acceptance of timed writing practice have been proven to have some qualitative reasonings. As authentic examples of students' responses, some reasons are presented in improved sentences as follows.

\section{Encouraging Writing Activity}

It is a good way to encourage novice writers to overcome their so called writers block and it gives students the opportunity to write, which may lead to an improvement in the quality of their writing.

\section{Improving Time Management and Control}

The time management has a biggest point from this activity because it can affect the final result of our paragraph. When we have a long time to make a paragraph, 
we can make it so long paragraph and so various topics. But, on the timed-writing activity we just have some minutes to do our paragraph. So, we must be wise to control the topics that we want to put on our paragraph.

(1) The strength of timed-writing method is on the time management, and controlling the topics. Because from this activity we have to finish our paragraph as well as the specified time.

(2) I can manage the time as good as possible. To do something we should manage the time. We know that Tine is priceless. Also in Writing Practice, I can write kindly by managing time well.

(3) I become good at time management and easily to adapt into a new environment

(4) I know how to manage it can I will writes the deadlines in the calendar so I would not miss an important deadline.

(5) I can control my time well.

\section{Training Thinking Skills}

(1) It trains our aptness.

(2) Timed writing is something really good to me. I love the fact that we would always exercise brain and thinking-skill in a certain times.

(3) So, I will explain about the benefits of timed writing practice. So the first is think fast, we can think fast to find the title or the topic, the second is fast to find idea, we can fast to find idea to make a sentence, the third is fast make a sentence. Those can make us to be fast in making a sentence, and make us not to think long.

(4) Timed-writing makes me think fast.

(5) Timed writing can be a critical thinking. Usually I get inspiration to write because of under pressure to write immediately.

(6) My strength is that $i$ ama quick learner.

(7) I agree with the application of timed-writing in writing class. Because when writing in class the student must believe in the abilities he/she has and practice to be honest with himself/herself because when writing we should not search information from the internet and also do not ask friends who are beside us.

(8) When writing students are required to think critically. Thinking critically in writing what is being written and get an idea only from within his mind.

(9) I can find my best space of my writing skills and i can feel my natural instinct in writing. I think the pure of our writing ability can be seen in the pure writng activity (timed writing).

\section{Improving Writing Skills}

(1) We would learn manythings from writing. For example, we'll gain new vocabularies. And by the time, we would always learn from grammar mistaken that we've made.

(2) I can get fromtimed-writing practice is improvement of my writing skill that a little bit better than before. Perhaps before I had that class, writing class I actually don't know about how to make a good paragraph, and also how to make a good text too. But now I have already known about it, although it can't be a perfect text yet, but I try to do the best, to do with the mechanism of writing.

(3) I can improve my writing skill because in my past $i$ did not like writing and $i$ hate writing.

(4) To be honest, I got so much benefits from it. Beside that it will always get me a little bit better on writing each time. Writing also can improve our English skill. 
(5) The strength point of timed-writing is improvement of our writing skill. Because a mastery come from having a lot of practices, so if we had a lot of practices in writing, especially in writing class.

(6) The benefits of timed-writing practice is we are trained to be able to think quickly, so we can write quickly in handwriting. Because when we are too slow, we will lose a lot of time.

\section{Training Speed Writing}

(1) I will explain about the benefits of timed writing practice: the ability to write increases in speed and to find ideas or innovations easily.

(2) The benefits of timed-writing practice are I was trained to think quickly in finding new ideas and developing them in a topic. And it can also train speed and accuracy in writing. Then, it can train to make correct paragraph writing, especially the structure of correct writing, etc.

(3) The strengths of timed writing is, that we can learn to write and think quickly. I agree, because with application of timed writing give us many benefits. Example, we can learn to write and think quickly, we can find out as soon as we can act. And actually it's not difficult if we are accustomed to it

\section{Improving Soft Skills}

(1) The strength of timed-writing isthat writing will form a wise and polite person. By writing the personality of the author will be more wise and polite. Because he has learned a lot and will continue to learn when he continues to develop his writing.

(2) It will improve our critical thinking as well and we'll solve the problems by discipline.

(3) I can't find a weakness of timed-writing practice, I think it full of benefit. Maybe time for timed-writing should add, 30 minutes for example because in that time we can make more good paragraph with think about the structure in first 5 minutes and a rest of time we can made a paragraph effectively.

\section{Giving a Challenging Activity}

(1) I think, the advantage is that we are like getting a challenge that we have to solve the problem (topic). Whether we want it or not, we have to finish it in a short time and on time and also this can train our level of focus at that moment.

(2) The benefits of time-writing practice such as I train my brain to make good sentences, I can think many knowledges never I knew before. I mean that I can imagine and plan something. I can also know the latest information, article and news. So I can get many knowledges that I do not get in the class.

(3) It can make us to be critical thinking, study many vocabularies and tenses.

(4) The benefits that students can get from their timed-writing practice are opening wider insight,

(5) Timed-writing can make spirit for me, sharpen our ability in setting time and measure the extent to which our ability in writing briefly

(6) In my opinion, I get a lot of benefits. I am always trained every day to write English. At first I was surprised when I had to write English. But, now I always write English, because English can help me learn about new vocabulary. 


\section{Improving Concentration and Accuracy}

(1) It can also be used to know my writing ability.

(2) It can train to find out new ideas quickly, concentration and can learn about how to make a good and right in writing. It can train speed and accuracy in writing.

\section{Disagreement on the Application of Timed Writing Practice}

Those who disagree with the application of timed writing (13\%, very low category) gives the following reasoning: The benefit of Timed-writing practice is if $i$ have time to warming up my English writing skill i can arrange better sentence in my text but if without warming up I can not make better my sentence because i have not prepared yet.

\section{Having No Sufficient Preparation}

(1) I have several reasons todisagree withtime writing. For the first $\mathrm{i}$ feel lack of time with the limitation time, it make me not being able to pour my maximum ideas. The next of my reason is that can't think more for every theme.

(2) The weakness from timed-writing activity is on the words composition on the paragraph. Because the topic that give is so spontaneous, than the students or the writers also give the spontaneous reason to the topic that was just decided. They certainly can feel very nervous and it make them so blind mind.

\section{Expecting Variation of Activity}

Actually I little bit disagree if timed-writing activity always give into every class meeting. Because it can make the students or the writers feel bored and have no sense of enthusiasm to join this activity. I prefer to mix the material and intersperse the timed-writing activity to not only write a paragraph, but also write a poem or song lyrics. So, the students or the writers will not be bored and enjoy the class with full enthusiasm

\section{Being Too Fast}

(1) No, I disagree because i don't have time to prepare it so my writing is not good.

(2) I disagreewith timed-writing because it's too fast.

(3) I disagree because it is limited by the time which makes me unable to write well. I have trouble finding vocab and making sentences. I think 30 minutes is a short time

\section{Feeling Nervous and confused}

(1) And the weakness of timed writing is we will often feel nervous and confused when we don't have a good idea, while time is going on.

(2) It is unconnected between brain and hand. I think something but my hand writes something else

Those who disgree with TWP application seem to hope that the lecturer assign a timed writing every one to two weeks. They do not want to do it too often because timed writing is an output activity. While it is a good measure of a student's language acquisition, the acquisition process itself can not occur without additional comprehensible input. If you are assigning timed writings before that additional input occurs, there is not much point to the exercise. It is advisible that the application of timed writing also pay attention to their reasons. 


\section{No Opinion}

Two students (35) provided no opinion of the application of timed writing. This belongs to very low category.

I dont have any idea with application of TWP.

Timed Writing will surely bring objectivity to the writing instruction. That objectivity will help the leacture and students to discover what works and what does not work in teaching writing. Hopefully, the timed writing system is something that the students can use, and then grow and adapt. Objectivity in writing instruction is something that is lacking.

\section{CONCLUSION}

The research shows that twenty five students (81\%) agree with the application of TWP which belong to very high category. Four students $(13 \%)$ disagree and the disagreement belongs to very low category. Twostudents $(6 \%)$ give no choice and belongs to very low category. Timed writing application is agreed and perceived as (1) Encouraging Writing Activity, (2) Improving Time Management and Control, (3) Training Thinking Skills, (4) Improving Writing Skills, (5)Training Speed Writing, (6) Improving Soft Skills, (7) Giving Challenging Activity, and (8) Improving Concentration and Accuracy. The reasons from those who disagree are: (1) Feeling nervous and confused(2) Having insufficient preparation time, and (3) Expecting Variation of Activity, In conclusion, timed writing are positively accepted and perceived by the students. The reasonings from those who disagree must be taken into consideration for future betterment. Based on the research findings, the timed writing, accordingly, can be used as a technique or a strategy to be integrated in a discourse-based writing material with a timed-writing technique for students of English teacher education program.

\section{REFERENCES}

Aidinlou, Nader Assadi. (2004). A Discourse-based Teaching of Writing for Iranian EFL Students: A SystemicPerspective. Journal of English Language Teaching and Learning 8.http://home.utah.edu/ u0404503/PDF/School/Power\%20Points/why_writing_is_s o important.pdf

Ayotte, Stacey-Beth Mackowiak. (2018). Timed-writing in the Foreign Language Classroom: Does practice make perfect?http://crisolenguas.uprrp.edu/Articles/Timedwriting $\% 20 \mathrm{in} \% 20$ the $\%$ 20Foreign $\% 20$ Lanfuage $\% 20$ classroom.pdf

Bounds, Gwendolyn. (2010). In Digital Age, Does Handwriting Still Matter?inhttps://blogs.wsj.com/juggle/2010/10/04/in-digital-age-doeshandwriting-still-matter/ 
Celce-Murcia, Mariana. (2018). Rethinking the Role of Communicative competence in Language Teaching. In https://www.google.com/search?q=Rethinking +the+Role+of+Communicativ $\mathrm{e}+$ Competence + in + Language + Teaching $+\&$ ie $=$ utf- $8 \& o e=$ utf$\underline{8 \& c l i e n t=\text { firefox-b }}($ accessed on 16 September 2018)

Celce-Murcia M, Olshtain E (2000) Discourse and Context in Language Teaching. Cambridge University Press, Cambridge .

Claire Whittaker. (2005-8). Redesigning a blended learning course: Introducing new technologies for ELT in Managing Change in English language Teaching: Learning from Experiences; British Council edited by Christopher Tribble $\subset$ British Council 2012 Brand and Design/B33010 Spring Gardens London SW1A 2BN, UK www.britishcouncil.org

ETS. (1996). Toefl Test of Written English Guide. Princeton: Educational Testing Service

Gall, Meredith and Gall, Joyce, Borg, Walter. (2003) .Educational research: An Introduction (7th ed.). New York: Longman.

Hosseini, Monirosadatand MohamadEhsanTaghizadeh,MohamadJafreZainolAbedin,, ElhamNaseri. (2013). Thethe Importance of EFL Learners' writing Skill:Is there any Relation between Writing Skill andContent Score of English Essay Test? International Letters of Social and Humanistic Sciences Online: 2013-0925 ISSN: 2300-2697, Vol. 6, pp 1-12. doi:10.18052/www.scipress.com/ILSHS.6.1 C 2013 SciPress Ltd., Switzerland

Lougheed, Lin. (2008). Barron's IELTS International English Language Testing System. Tangerang: BinarupaAksara Publishing, Co.

Lund, R Elisabeth. (2010). Handwriting as a tool for learning in ELT in ELT Journal, Volume 70, Issue 1, 1 January 2016, Pages 48-56. https://doi.org/10.1093/elt/ccv048

Megawangi, Ratna. (2004). PendidikanKarakterBangsaSebagaiSolusiTepatuntukMembangunBangsa. Jakarta: Indonesia Heritage Foundation.

O’Malley, J. Michael and Pierce, Lorraine Valdez. (1996). Authentic Assessment for English Language Learners. Practical Approaches for Teachers. US: Addison-Wesley Publishing Company, Inc. p. 143 (Holistic scoring rubric Developed by ESL teachers, Prince William County Public Schools, Virginia)

Oshima, A and Ann Hogue. (2006). Writing Academic English. New York: Pearson Education (pp.263-330).

Putra, Ichsan S and AryantiPratiwi. (2005). Suksesdengan Soft Skills. Bandung: DirektoratPendidikanInstitutTeknologi Bandung. P. 5 
Rodgers, Derek. (2018). Using Timed Practice with Repeated Writings to Promote Sentence-Writing Fluency.Posted on: May 1, 2018 in https://iowareadingresearch.org/blog/teaching-writing-fluency-timedpractice-part-1

Syafei, Muh. (2012). Backwash Effects of Portfolio Assessment in Academic Writing Classes. TEFLIN Journal. Volume 23 Number 2 July 2012. p 22. http://www.teflin.org/journal/index.php/journal/article/download/146/138

Syafei, Muh. (2014). Enhancing Students' Soft Skills through PWP (Pressure Writing Practice): A Reflection in a Writing Class. A paper presented at UNNES ELTLT International Conference. http://eprints.umk.ac.id/4461/2/daftar_isi_prosiding_ELTLT_3.pdf

https://www.howjournalcolombia.org/index.php/how/article/view/57Blended Learning in the Teaching of English as a Foreign Language: An Educational Challenge

http://www.knowledgewave.com/blog/benefits-of-blended-learning. US Dept of Education, 2010. 